\title{
Cish attenuates proximal TCR-signaling and CD8+ T cell immunity
}

\author{
Douglas Palmer*, Geoffery Guittard, Shashank Patel, Lawrence E Samelson, Nicholas P Restifo \\ From Society for Immunotherapy of Cancer 29th Annual Meeting \\ National Harbor, MD, USA. 6-9 November 2014
}

$\mathrm{CD} 8^{+} \mathrm{T}$ cells are potent killers of infected cells and tumors, specifically recognizing their targets through the $\mathrm{T}$ cell receptor (TCR). While much has been revealed about the activation of TCR signaling, negative regulation of this pathway remains incompletely elucidated. We report that Cish plays an inhibitory role in immunity to infection and adoptive transfer of Cish-deficient CD8 ${ }^{+}$ $\mathrm{T}$ cells eliminated established cancer. Cish deletion resulted in augmented acute phospholipase Cg1 (PLCg1) activation, $\mathrm{Ca}^{2+}$ flux, NFAT and NFkB activity, and cytokine release. Conversely, Cish reconstitution decreased $\mathrm{Ca}^{2}$ ${ }^{+}$flux, T cell polyfunctionality and PLCg1 accumulation in microclusters. We found that Cish physically interacts with PLCg1, targeting it for degradation following TCR engagement. Our data reveals a central role for Cish as a negative regulator of proximal TCR signaling and $\mathrm{CD} 8^{+} \mathrm{T}$ cell immunity and identifies a new targetable interaction for immune-based therapy of infectious disease and cancer.

Published: 6 November 2014

doi:10.1186/2051-1426-2-S3-P32

Cite this article as: Palmer et al:: Cish attenuates proximal TCR-signaling and CD8+ T cell immunity. Journal for ImmunoTherapy of Cancer 2014 2(Suppl 3):P32.
Submit your next manuscript to BioMed Central and take full advantage of:

- Convenient online submission

- Thorough peer review

- No space constraints or color figure charges

- Immediate publication on acceptance

- Inclusion in PubMed, CAS, Scopus and Google Scholar

- Research which is freely available for redistribution 